\title{
Notes on a Central Asian Notebook
}

\begin{abstract}
Among the personal notebooks from nineteenth-century Central Asia, the manuscript NLR PNS 561 (National Library of Russia, Persian - New Series), kept at Saint Petersburg, occupies a special position. It is a multilayered manuscript with two main layers from the 1870s and the 1920s-1930s, respectively. In the second layer in particular, the manuscript is both a multi-script and a multigraphic artifact. Some parts of this layer are quite likely autographs of a leading Bukharan intellectual, Abdarrauf Fitrat (1885-1938). This paper is a detailed description of the manuscript that also assesses the ascription of discrete manuscript sections to Fitrat as autographs.
\end{abstract}

\section{Introduction}

Sometimes a single manuscript offers a window into a wide array of research questions. One such manuscript will be presented here. The questions are related to the manuscript's own history and to the history of alphabet changes in the Soviet Union. The manuscript also prompts consideration of the nature of composite manuscripts more generally and of autographs in particular.

The manuscript is kept at the National Library of Russia (NLR), with the shelf number PNS 561. The acronym PNS stands for 'Persian - New Series' (Persidski - Novaia Seriia). The manuscript was acquired by the library in 2002 together with a number of other manuscripts from a Russian citizen with family roots in Tajikistan. ${ }^{1}$

The manuscript is dated to the end of the nineteenth century and the 1920s30s and comes from Central Asia: 'viii and 66 fols, $25,5 \times 15 \mathrm{~cm}$. Oriental and European paper. Different hands. Entries are written with qalam in black ink, (European) pen, and pencil.' The catalogue description also notes that the cover

\footnotetext{
1 I owe this information to Olga Yastrebova, who is responsible for the Persian collection at the NLR and was also involved in writing the corresponding parts of the New Acquisitions catalogue (Personal e-mail message from Olga Yastrebova, 15 Oct. 2020). I thank her for pointing this out to me, and also for making the catalogue (see note 3) available to me.
} 
was made by Mīr Ṣālih Ṣaḥhāf ('the Bookbinder') and is dated 1274 AH / 1857$1858 \mathrm{CE}^{2}$ As for the content, the description has the following:

A booklet with various entries and excerpts from different periods. The older entries include: a folkloric, fairytale-like story without beginning $\left(2-4^{v}\right)$; models of various qadi decisions and other official documents (11-25 ); models of letters to high-ranking persons, members of the family, friends, and so on $\left(26^{\mathrm{v}}-37^{\mathrm{v}}\right)$; recipes of folk medicine $\left(60-61^{\mathrm{v}}\right)$; poems in Persian and Turki [in different places in the manuscript] [the description then names the authors of the poems; they are left out here]. On fol. 53 there are four notes, in pencil, on the birth dates of four persons (20 Feb. 1904; 24 Feb. 1906; 9 Jan. 1913; 17 Jan. 1915). The verses on fols $38-40,41^{\mathrm{v}}, 47^{\mathrm{v}}-52,55^{\mathrm{v}}-56$ apparently are autographs by Abdarrauf Fitrat (1885-1938), which he wrote in the 1920s or 1930s. Probably, he also wrote the grammatical and syntactic analyses of sentences on fols $40^{\mathrm{v}}-41$. There are entries in Tajik written in Roman script on fols 53, 54, 55. Empty space on the pages is filled with computations and the solution to equations. ${ }^{3}$

The last remark in the description is that there are eight sheets loosely deposited into the volume at its beginning; these sheets include fragments (single pages) of lithographed books, in both Persian and Turki.

This specimen is thus a multilayered manuscript: it was not written in one go by one or several persons, but at different stages, with a considerable lapse of time between the layers. It also is a multilingual manuscript since it has entries in Persian and Tajik, Arabic, and Turki; there also is one entry in Russian. Moreover, it is a multi-script manuscript: entries are in Arabic as well as Roman script, and the Russian entry is in Cyrillic script. It is furthermore a multigraphic manuscript: it contains not only text but also numerals, computations, and arithmetic.

Besides that, the description claims that the manuscript has autograph sections, which would indicate that at least these sections are an original. More specifically, this manuscript is a personal notebook or rather has parts of two personal notebooks, one in each layer, as will be shown. ${ }^{4}$

2 This bookbinder is known: another manuscript from his workshop is in Tashkent, Institute of Oriental Studies, Fond 2 ('dubletnyi fond') 524, dated 1268/1851-2. Gulomov et al. 2000, 145 no. 1584.

3 Yastrebova and Vasil'eva 2017, 146-7. All translations are my own. The description is quoted at length because it emphasizes the heterogeneous nature of the manuscript. I have not seen the manuscript itself, but am working from reproductions. Thanks to the National Library of Russia for making the reproductions available to me so speedily.

4 The term 'original' is used here with reference to the debate surrounding it within the Cluster of Excellence 'Understanding Written Artefacts' at Hamburg University, and in particular within the relevant research field, 'Creating Originals'. A very preliminary explanation was 
And finally, the manuscript is a composite manuscript because it was rebound: the object now kept at Saint Petersburg is not the one bound by Mir Saaliḥ; the binding was in fact refashioned, and perhaps the binding made by Mìr Șālị was not intended for the book we have today. ${ }^{5}$

Thus, even though this is a small manuscript - a mere 66 plus 8 sheets - it has lots of interesting features.

\section{Details of the description}

\subsection{The first layer}

The description in the catalogue is correct, but it does not do justice to the complexity of the manuscript.

The date on the cover can be read clearly: $1274 \mathrm{AH}(1857-1858 \mathrm{CE})$. This means that the cover is considerably earlier than the first dated entries in the manuscript, which come from the 1290s AH / 1870s CE. It is of course possible that nothing was written in the book for roughly fifteen years after it was produced, but that seems improbable. It is more likely that in the beginning the cover did not belong to the manuscript at all, and that the cover was instead reused at some unknown point for the present manuscript. This conclusion is supported by the observation that the manuscript was indeed rebound (see below). This question and other questions raised by the catalogue description e.g. regarding the paper: the description states that different papers were used - can only be tackled if one has access to the material object. I have not seen the manuscript itself but am working from reproductions which I obtained from the National Library of Russia (see Fig. 1).

For what follows, the loose sheets at the beginning will be disregarded as well as the various entries on the first ten folios. The analysis starts with the

given in the research proposal (June 2019). The following passage is a starting point for a longer debate, which is far from having reached any conclusion: 'In many manuscript cultures, however, some written artefacts are assigned a special status, the status of an original, and such objects are given a higher value in many different ways: they are collected, bought and sold at high prices, carefully preserved, treated with respect and even awe; they have great efficacy in legal, religious, economic, literary and other contexts. [...] The numerous types include autographs, art works, legal documents, letters, diaries, notes, test and experiment reports, minutes and proceedings, among many others.' In this understanding, autographs and notebooks would both qualify as originals.

5 Friedrich and Schwarke 2016, 1-26. 
transition from fol. 10 to 11. These two folios clearly do not belong together. The block is broken, the binding threads seem disordered. And the format of fol. 11 is a bit larger than that of fol. 10. Moreover, the paper does not match; there is a difference in colour. Fol. $10^{\mathrm{v}}$ is empty, and the text on fol. $11^{\mathrm{r}}$ does not start with a heading, but rather transitions straight into a legal document. This break in continuity between fols 10 and 11 shows that the manuscript is a composite manuscript: a manuscript with various parts which were not produced in a single effort, but were joined together later, in most cases through binding. This definition applies to what happened here as well, and as mentioned before, it is altogether possible that an older cover was used.

On fol. $11^{\mathrm{r}}$, a collection of models or copies of qadi documents begins. As a general rule, in nineteenth-century Central Asian practice, such documents start with the date on which the corresponding action took place. In the case of models or copies, the dates are replaced by 'so and so', in Arabic kadha ${ }^{6}{ }^{6}$ This is also the case in our document. The writer of these pages overlined the first words of an item. The last words are a formula which is also typical for qadi documents, 'and this was in the presence of Muslims [as witnesses]', wa-kāna dhalika bi-mahdar min al-musliminn. In this manuscript, the formula is characteristically written in an abridged form, as is frequently the case elsewhere. The next item begins on a new line, with the first words again overlined and so forth. The compiler therefore took care to mark the beginnings and the endings of the individual entries.

The majority of entries in this part are undated, but there are some exceptions, most of which date to the 1290s AH /1870s CE. These dates are in line with other dates in this part of the manuscript - all from the 1290s AH.

The catalogue description quoted above enumerates other parts with very diverse content, and it can be added that the layout changes a great deal as well. Poetry is written in two or more columns, with the script going at a 45 degree angle to the left, and an occasional perpendicular line in the middle of the page. The older layer in the present manuscript therefore resembles other manuscripts - most of them much larger - which have been categorized as personal notebooks.

Notebooks kept by legal practitioners, qadis and muftis, survive from Central Asia in relatively large numbers. In Tashkent alone, in the library of the Institute for Oriental Studies, there are about fifty of them. They vary enormously,

\footnotetext{
6 Arabic was the main language for legal treatises. The legal terminology in Central Asia is all in Arabic, even in legal documents that are otherwise in Persian or Turki. A kind of shariatic legalese is the result.
} 
but many have one feature in common: their heterogeneity. They reflect the multifarious activities of their writers. These notebooks contain not only legal matter, but also poetry, texts and drawings on occult sciences, guidelines for healing - mostly these guidelines involve the writing of amulets and other magical agents. Such elements are also present in the manuscript under review here. ${ }^{7}$ For instance, there is some poetry in Turki. ${ }^{8}$ Bilingualism - Persian and Turki - was widespread in Central Asia, and to have multilingual manuscripts (with two or three languages: Persian, Turki, and possibly Arabic, as in our manuscript) is the rule rather than the exception.

To sum up for the first layer or layers: The cover was made in the $1270 \mathrm{~s} \mathrm{AH} \mathrm{/}$ 1850s CE, but the oldest dated text entries are from the 1290s AH / 1870s CE. The entries with dates all come from the 1290s AH and are mostly legal matter. This older layer also has letter samples, poetry, personal notes, and so on, as the description points out. It is hard to tell how much in this layer was written in one hand only. The writer is nowhere identified; there is no name or names, no signature, no seal. Some texts carry place names, and the place where something was written is always Bukhara. So it is certain that this layer was written in Bukhara, by a man active in the legal system, most probably as a qadi, who also had other interests, mainly in poetry.

\subsection{The second layer}

The second layer - dated in the description to the 1930s - is even more complicated. There is no point in the manuscript where the first layer stops and the second starts. Quite the opposite: the first layer appears again and again until the very end of the manuscript. The second layer is first visible on fol. $26^{\mathrm{r}}$ (see Fig. 2).

On the left side, fol. $26^{\mathrm{r}}$, there is an entry in black ink, but probably written with a European pen, made of steel instead of reed. The script is Roman, the language Tajik. Closely related to Persian, Tajik was the first language for a

7 These notebooks are called jung in Central Asia. This is an understudied genre in Central Asian manuscriptology. Pioneering studies have been undertaken by Gulomov 2012 and Saidakbar Mukhammadaminov 2017. James Pickett's PhD dissertation, now published as a book (Pickett 2020), is a groundbreaking contribution to the intellectual history of nineteenthcentury Bukhara. It is through Pickett's work that I became aware of the manuscript examined in this article. I have myself examined some other jung manuscripts in more detail in Paul (forthcoming).

8 MS NLR PNS 561, fols $56^{\mathrm{v}}-57^{\mathrm{r}}$. 
majority of the urban population in Bukhara during the late nineteenth century. Tajik was written in Roman script from 1928/1929 to 1939/1940, when Cyrillic was introduced. ${ }^{9}$ Thus, the entry could hardly have been written earlier than the mid to late 1920s and was certainly not written later than 1940 . There is, then, a distance in time of about fifty years between the two layers, that is, two generations. And since there is no information about the writer of the first layer, nothing can be said about the possible relationship between the writers. In general, it is unknown how the book made its way from the first writer and owner to the second..$^{10}$

The hand which wrote the lines is clearly not at ease with the script. The forms of the letters betray that the teachers themselves (about whom no information is available) must have been unfamiliar with Roman script and were probably Russians or otherwise literate in Cyrillic. The writing in the first line breaks off in the middle of a word, and the second line repeats the first and then goes on a bit further. The text is probably an exercise: 'Open steppe and beautiful garden and fine weather' and so on.

A bit below the writing exercise there are exercises in arithmetic. These exercises are written in pencil, a writing tool unknown in Bukhara until the nineteenth century but clearly there in the twentieth. The numerals used are both the 'Oriental' and the 'European' Arabic numerals. For the exercises in Oriental numerals, there are explanations in Arabic script and language.

And there is another, longer text in Tajik, in Roman script; written in pencil, it is hardly legible in the reproduction. There are some mistakes in this section: the writer repeats syllables in what is an attempt at writing verse. ${ }^{11}$

This layer offers a glimpse of what a script reform can mean to intellectuals, to writers whose hands were used to writing without having to think about how, only about what, they wrote. And the script reform also meant a reform of numerals.

\footnotetext{
9 Script reform in the Soviet Union is best covered by Baldauf 1993. For Tajik in particular, see Rzehak 2001.

10 The several notes which we find on the inner side of the cover are not helpful. There is a note about the birth of a son, dated to the Year of the Pig 1305 (1887-1888), and another one,

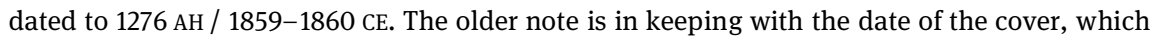
was made just two years earlier, while the later one could refer to a later owner.

11 The first two lines read: 'Man az bigzaşata ma'zuram * man az ajanda masrūrūram' ('I am free from the past * I am happy with the future' [or: 'I am looking forward to the future']). The repetition of the syllable $r \bar{u}$ in the last word is a mistake; it should be masrüram ('I am happy'). The reading bigzaşta is doubtful. The writing of the long vowels (such as $\bar{u}$ ) is not always observed.
} 
Writing Tajik in Roman script occurs on quite a number of folios in the manuscript, as detailed in the catalogue description quoted above. Moreover, there is also one item written in Cyrillic: a postal address on fol. 39v (see Fig. 3).

The town of Uratiube in Tajikistan is mentioned, as well as a location in the region of Ural'sk, today in western Kazakhstan. ${ }^{12}$ The Russian elements in the address - e.g. the name of the street, Pionerskaia ulitsa - are written phonetically. ${ }^{13}$ Tajikistan is called an 'SSR', which provides us a clue as to the dating: Tajikistan was made an SSR only in 1929, and therefore this entry must be later than that.

Next to the address, there is an entry in a completely different hand, a kind of intellectual scribble. But since the ink is the same colour - a pale violet or purple - it is quite possible that the writer was the same. The Cyrillic letters are larger, written with more impact, and certainly more slowly than the Arabic script next to them, but the pen could also be the same. Or did writers use different pens for writing in European scripts, from left to right, and in Arabic script, from right to left?

A part of the page has been cut off, just below the address. This has happened in various places in the manuscript; such cuts can be observed in other Central Asian notebooks as well. Probably such manuscripts also served as a reservoir for paper. ${ }^{14}$ In this case, perhaps the address was written again, and then the corresponding part of the page cut out and glued to the object which was being sent.

The hand next to the address reappears in many places in the second layer of the manuscript: this is the script that Yastrebova attributes to Abdarrauf Fitrat. ${ }^{15}$ Fitrat was a leading representative of the Bukharan modernist intellectuals of the early twentieth century. He joined the Bolsheviks after the revolution, was part of the Bukharan revolutionary government, but soon came into conflict with the leadership of the Communist Party. After 1924, when he came back to Central Asia following a forced stay in Moscow, he spent some years in Samarqand and Tashkent, working in the nascent Soviet academic system, and he was also involved in the Romanisation of Tajik: it was his proposal for the

12 The name of the place could be read as Shadrin or Tadrin. I have been unable to identify such a place in the region of Ural'sk. The Russian word oblast' ('administrative unit') comes with a non-Russian ending, oblaste, which may represent a Turki form.

13 The writer has Пиянирск. Улитса instead of Пионерск. Улица. Tajikistan comes as 'Tojikston', which sounds either Uzbek or Tajik.

14 An extreme example is the manuscript Tashkent, Institut for Oriental Studies no. 9767, where more than 40 sheets are missing. See Paul (forthcoming).

15 Outside of quotations, I write the name 'Fitrat' without diacritics. 
script reform which was eventually adopted ${ }^{16}$ His literary reputation is mostly due to his dramatic works, but he was a prolific writer in many fields, writing in both Turki and Persian. At the end, he fell victim to the Stalinist state terror and was executed without trial in October 1938 in Tashkent. ${ }^{17}$

\section{An autograph by Fitrat?}

For a number of reasons, Yastrebova's inference seems sound. Some entries indeed were probably written by Fitrat himself, and these entries are proof that he used this manuscript as a notebook for drafts, mostly of poetry, but also of letters, journal articles, and speeches. If the grammatical explanations are also his, as Yastrebova believes, their presence may relate to his work on Tajik grammar.

My analysis of the second-layer components in this hand starts with this short poem, four lines in all (Fig. 4a). At first the poem looks like a quatrain. Since the lines are written in a careful hand, they should be easy to read, but this impression is deceiving because nearly all the diacritical dots are missing. There are, however, other versions of the same text on other folios. By comparing the versions, it becomes clear that this is no quatrain, but a longer poem of ten lines (five verses, ten hemistichs). There are notable variants. In one version, we have Täjikistān instead of 'ālam at the beginning of line 6 (fol. $51^{\mathrm{v}}$, Fig. 4d), a more nationalist outlook: it is the home country instead of the whole world that ought to be filled with light. In two versions, lines 7 and 8 have been erased (Figs 4b and 4d); in one version, a word in line 4 (mullāyān, 'mullahs') has been blackened (Fig. 4c), and attempts at blackening that word are evident in another version (Fig. 4d). Most probably, this was done years after the poem was written (see below). What follows is the complete poem in Persian and in translation:

\footnotetext{
Ahl-i istithmār-rā maqhūr mī-bāyast kard

Luṭf pur rạ̣matkish muzdūr mī-bāyast kard

Tā ba-dunyā chashm bu-gushāyand dīgar ba'd az in

Cش Chashm-i mullāyān-i khwābīn kūr mī-bāyast kard

از ضياء شعل عرفان نو شمع علم
}

16 Borjian 1999, 566.

17 For a short introduction, see Borjian 1999. 
عالم را يُر ضياء نور ميبايست كرد

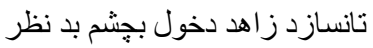

دختر ان خوب از دستور ميبايست كرد دئن

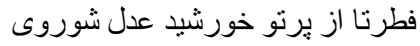

ظلمت ظلم شرر را دور مئد ميبايست كرد
'Ālam-rā pur dịyā'-i nūr mī-bāyast kard

Tā na-sāzad zāhid dukhūl ba-chashm-i bad-nazar

Dukhtarān-i khūb az dastūr mī-bāyast kard

Fițratā az partū-yi khūrshīd-i 'adl-i shūrawī

Zulmat-i zulm-i sharar-rā dūr mī-bāyast kard

\title{
Translation:
}

\author{
The exploiters must be smashed \\ Workers must be treated with kindness and compassion \\ In order to make people open up their eyes again to the future \\ The eyes of the sleeping mullahs must be blinded \\ With the light of the flame of new knowledge, the flambeau of science \\ The world must be made full of light \\ In order to keep the ascetic [the religious zealot] from interfering, with his evil eye \\ The pretty girls must be freed [?] from the order [of veiling?] \\ Fițrat! From the sunlight of Soviet justice \\ The darkness of oppression and evil must be kept away ${ }^{18}$
}

One argument that these entries are in Fitrat's own hand is that this name occurs at the beginning of the last verse (penultimate hemistich). In classical Persian poetry, this is the place where the poet identifies himself, more often than not in an invocation, addressing himself. The form of this short poem is altogether classic in spite of its revolutionary content. ${ }^{19}$

Another argument is that when multiple versions of a single text appear in a single manuscript, many of them in the same hand, the entries are probably drafts. It is remarkable, however, that the neat version is so short - one would expect it to have been written at the end, when the poet had decided which version he would eventually publish or present or otherwise consider more or less final. It is possible, however, that Fitrat also wrote the neat version - calligraphic writing after all was part of a standard education.

18 The stress on girls and veiling makes one think of the campaign for the unveiling of women, the so-called hujūm campaign which started in 1927.

19 Fitrat wrote poetry in both Persian and Turki. After writing in Persian earlier in his career he turned to Turki, and it is his works in that language that are best known. But after the mid 1920s, he started to write and publish in Persian again, as well as in Tajik. Borjian 1999 remarks that Fitrat's works in Turki have been widely studied but that there is much less on his Persian and Tajik works. A literary analysis of the poem printed above is beyond the scope of the paper. See Hodgkin 2015. (I owe this reference to James Pickett.) I am unaware of any printed edition of this text. 
The manuscript contains another example of a draft and a neat version of the same text, on fol. $53^{\mathrm{r}}$. This is perhaps a draft for a poster, a journal article, or a speech. In it, the addressees - 'Dear comrades' - are called upon to work for the distribution of the newspaper 'The Tajik Voice', which is a paper that appeared in Samarqand during the 1920s. Fitrat is known to have contributed to this newspaper, for instance, with two articles in 1927 on the Romanisation of Tajik. ${ }^{20}$

Together, these factors make the character of the manuscript even clearer. In the second layer as well, it served as a notebook. Perhaps it was even a notebook for more than one person - on the bottom part of this page, someone noted his own birthdate and that of others, perhaps his brothers and sister: 'I, Hamīd, was born on Friday, Dhū l-Hijjja 17, 1321 hijrī, corresponding to February 20, 1904, of the Christian era'. ${ }^{21}$ These are the notes mentioned in the description in the catalogue, quoted above.

In general, however, the entries in the second layer reflect some of the main preoccupations of Abdarrauf Fitrat: revolutionary propaganda, the Romanisation of Tajik, and the use of Persian literary models for Soviet politics. Taken together, these features are strong evidence that the manuscript in question belonged to him during this period, perhaps from the mid 1920s into the 1930s. In the light of this conclusion, it is altogether possible that Fitrat also wrote the exercises in Roman script.

Most of the entries in this hand, likely that of Fitrat, are in a cursive script, written in pencil or copying pencil, not easily legible, at times with ligatures and special forms of letters. The layout changes from page to page, from entry to entry. This variability is indicative of the strictly personal use for which these entries were intended.

\section{Final phase}

There are still other entries which come from the final phase of the manuscript's documented use: another writer made entries after Fitrat's death, thus later than 1938. This man wrote on fol. $40^{\mathrm{r}}$, in Arabic: arqamahu Fitrat ghaffara 'anhu, 'Fitrat wrote this, may God pardon him', and similarly on fol. 52': rāqamahu Fițrat ghaffara 'anhu wa-sattara 'uyūbahu, with the formula 'and may God cover

20 Borjian 1999, 566.

21 The Christian date is given according to the old pre-revolutionary calendar, the Julian one, still used today by the Russian Orthodox Church. 
up his sins' added. Both notes are written in pencil, the note on fol. $40^{\mathrm{r}}$ is to be found in the upper right corner of the page (Fig. 4a). The same person was possibly responsible for blackening the word 'mullahs' in one of the versions of the poem quoted above (fol. 39v), attempting to do so in another (fol. 51 ${ }^{\mathrm{v}}$ ) in order to make the word illegible, and in erasing a verse in two places (fols 49 ${ }^{\mathrm{r}}, 51^{\mathrm{v}}$, Figs $4 \mathrm{~b}$ and 4d). Lines 7 and 8 therefore survive in one version only (fol. $38^{\mathrm{v}}$, Fig. 4c), which possibly escaped the eraser's attention. This man was very probably a mullah himself, with some knowledge of Arabic, and on the other side of the barricades as far as veiling and unveiling is concerned: he did not want the lines on veiling to survive, and he wanted to 'correct' Fitrat's anticlerical polemics. Nevertheless, he thought it worth while to identify Fitrat as the author and writer of these lines. Thus, his remarks betray a certain respect for the personality of Fitrat, even if he also distances himself from Fitrat on some points. ${ }^{22}$

A case can therefore be made for ascribing several parts of the manuscript to Fitrat's own hand. More research is required, in particular into other papers possibly written in his hand, but that investigation is beyond the scope of this contribution. If the ascription is correct, this manuscript offers a glimpse into the working routines of a leading Central Asian intellectual and political actor.

\section{Conclusion}

The manuscript shows that handwriting plays an important role even after the end of a manuscript culture. With the rise of print - introduced in Muslim Central Asia around 1900 - people did not stop writing manuscripts. Except that the manuscript books they wrote were no longer meant to be copied, since copying was no longer the central form of distributing texts. Fitrat also had many of his works printed and even worked for the printed press. But of course personal notebooks still served as diaries and contain drafts, letters, and many other kinds of notes.

The manuscript sits astride the transition from Arabic to other scripts for Tajik, the transition from the traditional qalam to steel pen and pencil, and the transition from manuscript to print culture. This transition also had an impact on the writing of notebooks: they seem to have fewer excerpts and copies, and instead contain more drafts.

22 The Arabic formulae quoted are standard and do not necessarily imply a judgement on the character of the deceased person. 


\section{Acknowledgements}

Special thanks to James Pickett who checked my English. Needless to say, all mistakes and inconsistencies remain my own.

\section{References}

Baldauf, Ingeborg (1993), Schriftreform und Schriftwechsel bei den muslimischen Russlandund Sowjettürken (1850-1937): ein Symptom ideengeschichtlicher und kulturpolitischer Entwicklungen (Bibliotheca Orientalis Hungarica, 40), Budapest: Akadémiai Kiadó.

Friedrich, Michael and Cosima Schwarke (2016), 'Introduction - Manuscripts as Evolving Entities', in Michael Friedrich and Cosima Schwarke (eds), One-Volume Libraries: Composite and Multiple-Text Manuscripts (Studies in Manuscript Cultures, 9), Berlin: De Gruyter, 1-26.

Gulomov, Sanjar et al. (2000), Handlist of Sufi manuscripts $\left(18^{\text {th }}-20^{\text {th }}\right.$ centuries) in the holdings of the Oriental Institute, Academy of Sciences, Republic of Uzbekistan, Berlin: Das Arabische Buch.

Gulomov, Sanjar (2012), ‘О некоторых подлинных документах из коллекций рукописных произведений фонда ИВ АН РУз' 'O nekotorykh podlinnykh dokumentakh iz kollektsii rukopisnykh proizvedenii fonda IV AN RUz', in Bakhtiyar Babadjanov and Kawahara Yayoi (eds), History and Culture of Central Asia, Tokyo: TIAS, Department of Islamic Area Studies, The University of Tokyo, 135-170.

Hodgkin, Samuel, (2015), 'Revolutionary Springtimes: Reading Soviet Persian-Tajik Poetry, from Ghazal to Lyric', in Matteo de Chiara and Evelin Grassi (eds), Iranian Languages and Literatures of Central Asia: From the Eighteenth Century to the Present (Studia Iranica, 57), Paris: Association pour l'avancement des Études Iraniennes, 273-305.

Mukhammadaminov, Saidakbar (2017), 'Джунг - сборник практикующего судьи Средней Азии (конец XVI - XIX век)'“Jung - sbornik praktikuiushchego traditsionnogo sud'i Srednei Azii (konets XVI-XIX vek)' [='Jung - the collection of practicing traditional judge of Central Asia (end of 16th century - 19th century)] IFEAC Working papers, 17 <ifeac. hypotheses.org/3217> (accessed on 12 February, 2021).

Paul, Jürgen (forthcoming): 'Mufti notebooks. A ğung manuscript from late 19th-century Bukhara', in David Durand-Guédy and Jürgen Paul (eds), By One's Own Hand - for One's Own Use (Studies in Manuscript Cultures).

Pickett, James (2020), Polymaths of Islam: Power and Networks of Knowledge in Central Asia, Ithaca NY: Cornell University Press.

Rzehak, Lutz (2001), Vom Persischen zum Tadschikischen: sprachliches Handeln und Sprachplanung zwischen Tradition, Moderne und Sowjetmacht (1900-1956), Wiesbaden: Reichert.

Yastrebova, O.M. and O.V. Vasil'eva (2017), Новые поступления в отдел рукописей 20012005. Рукописные книги арабской графики и другие материалы восточного происхождения. Novye postupleniia votdel rukopisei 2001-2005. Rukopisnye knigi arabskoi grafiki i drugie materialy vostochnogo proizkhozhdeniia, Saint Petersburg: Rossiiskaia natsional'naia biblioteka. 


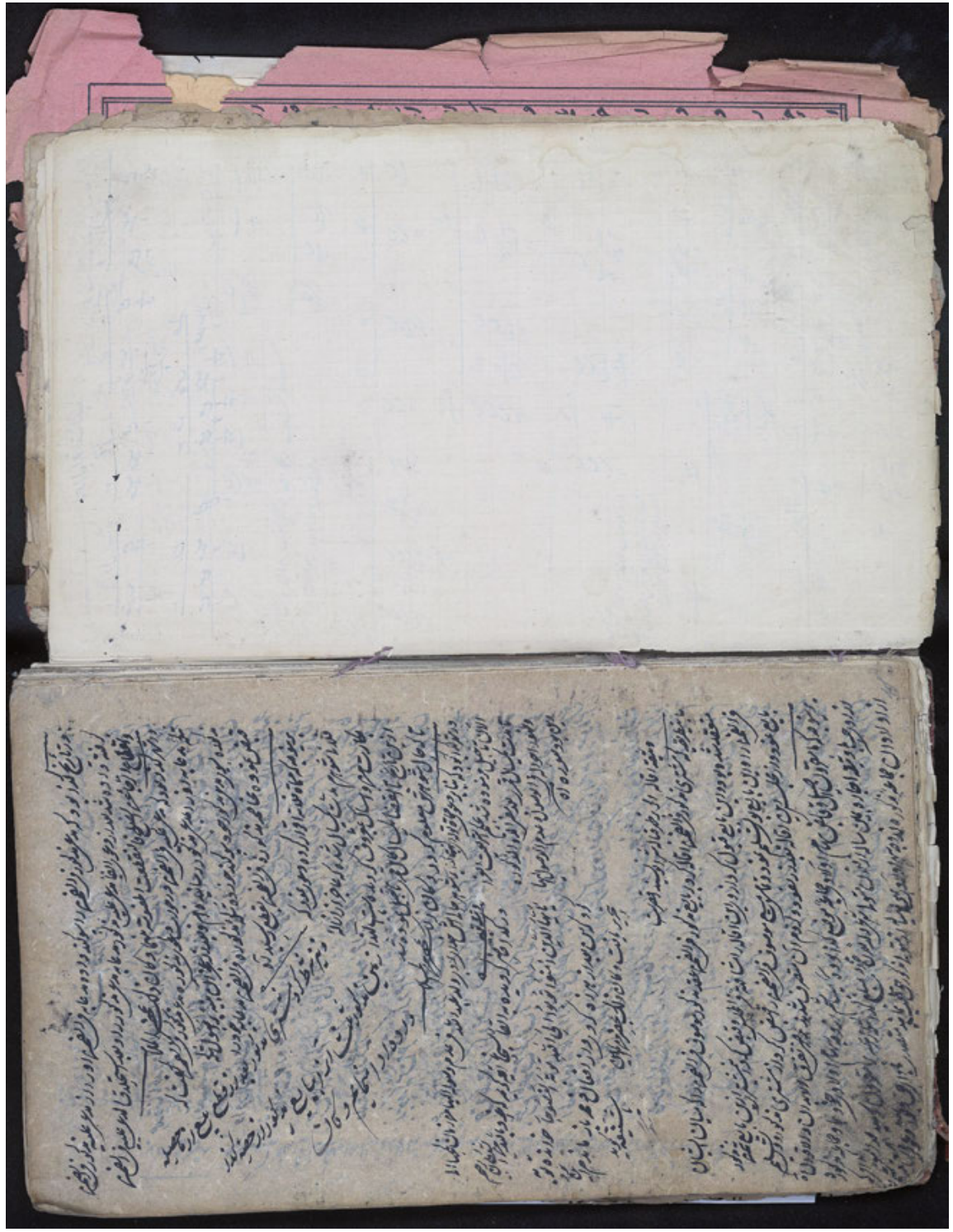

Fig. 1: MS NLR PNS 561, fols $10^{\vee}-11^{r}$. All figures courtesy of NLR. 


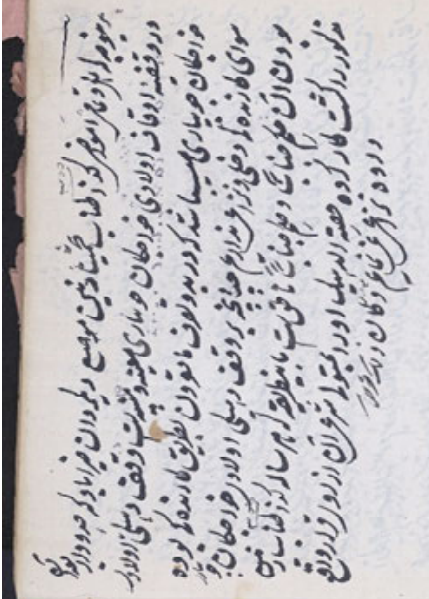

Fig. 2: MS NLR PNS 561, fols $25^{\mathrm{v}}-26^{\mathrm{r}}$. 


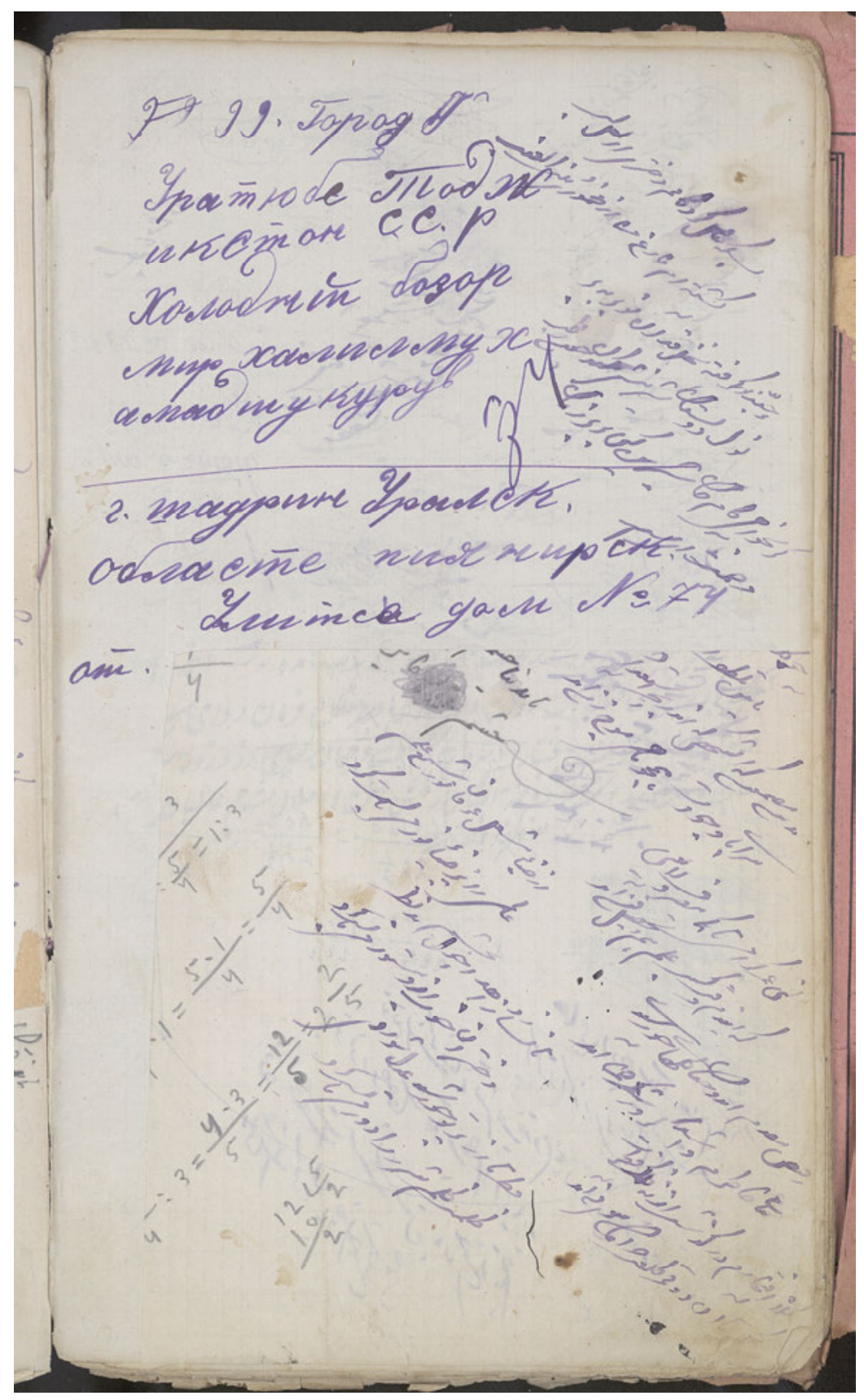

Fig. 3: MS NLR PNS 561, fol. 39v. 


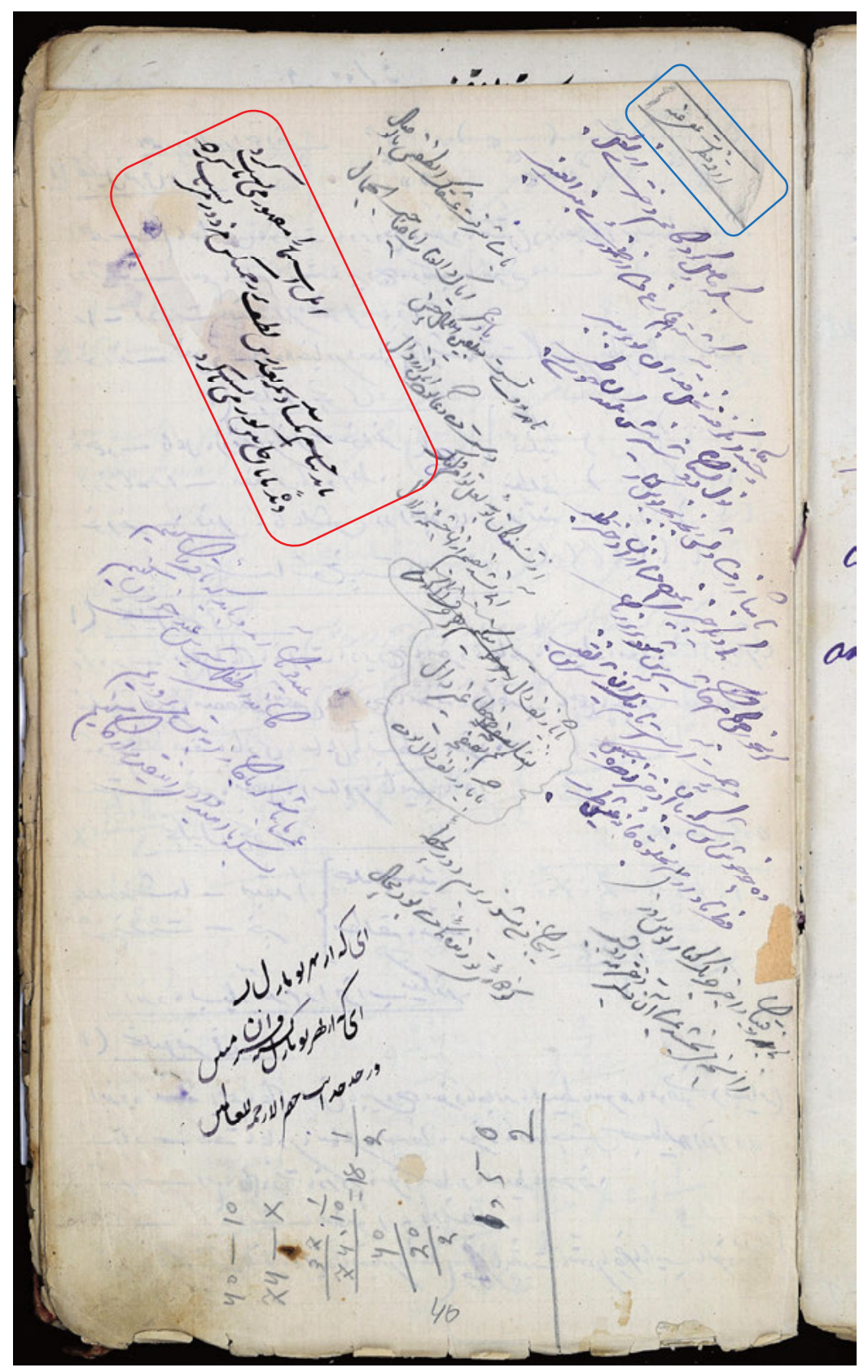

Fig. 4a: MS NLR PNS 561, fol. 40'. Four lines of a poem in careful hand (red) and the note 'arqamahu Fițrat ghaffara 'anhu' (blue). 


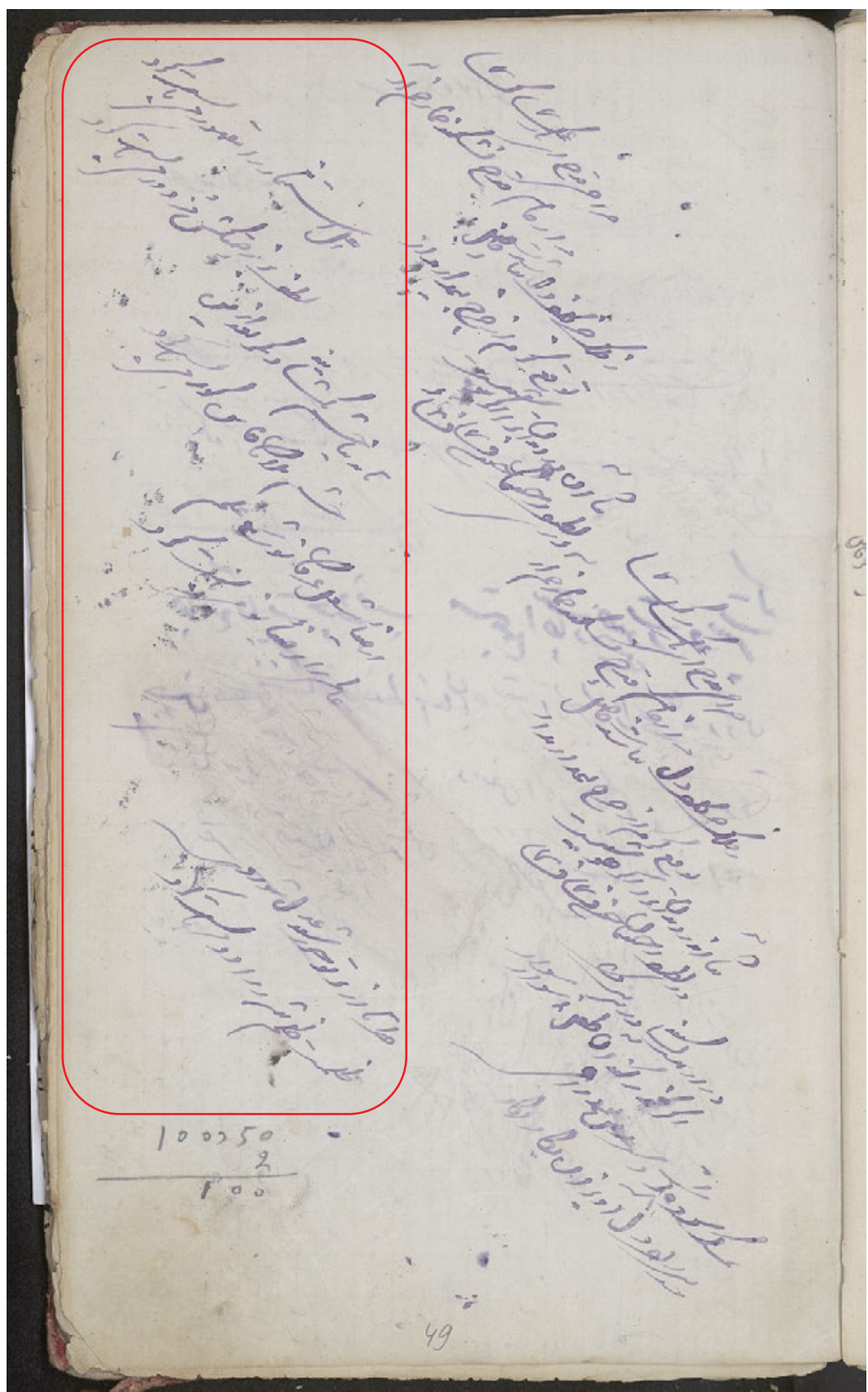

Fig. 4b: MS NLR PNS 561, fol. 49'. Longer version. Lines 7 and 8 erased. 


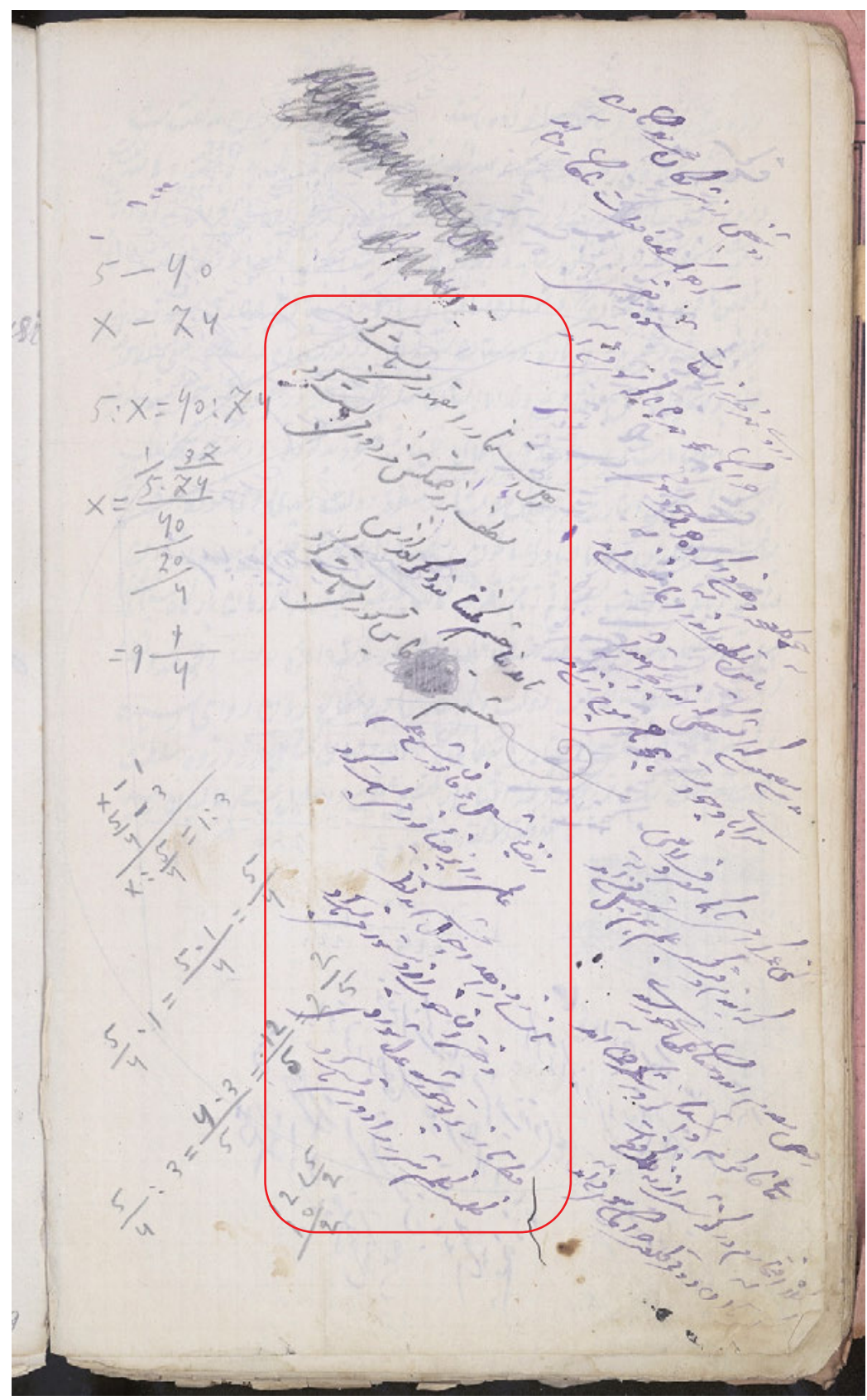

Fig. 4c: MS NLR PNS 561, fol. 38v․ Longer version. One word blackened (line 4): mullāyān. 


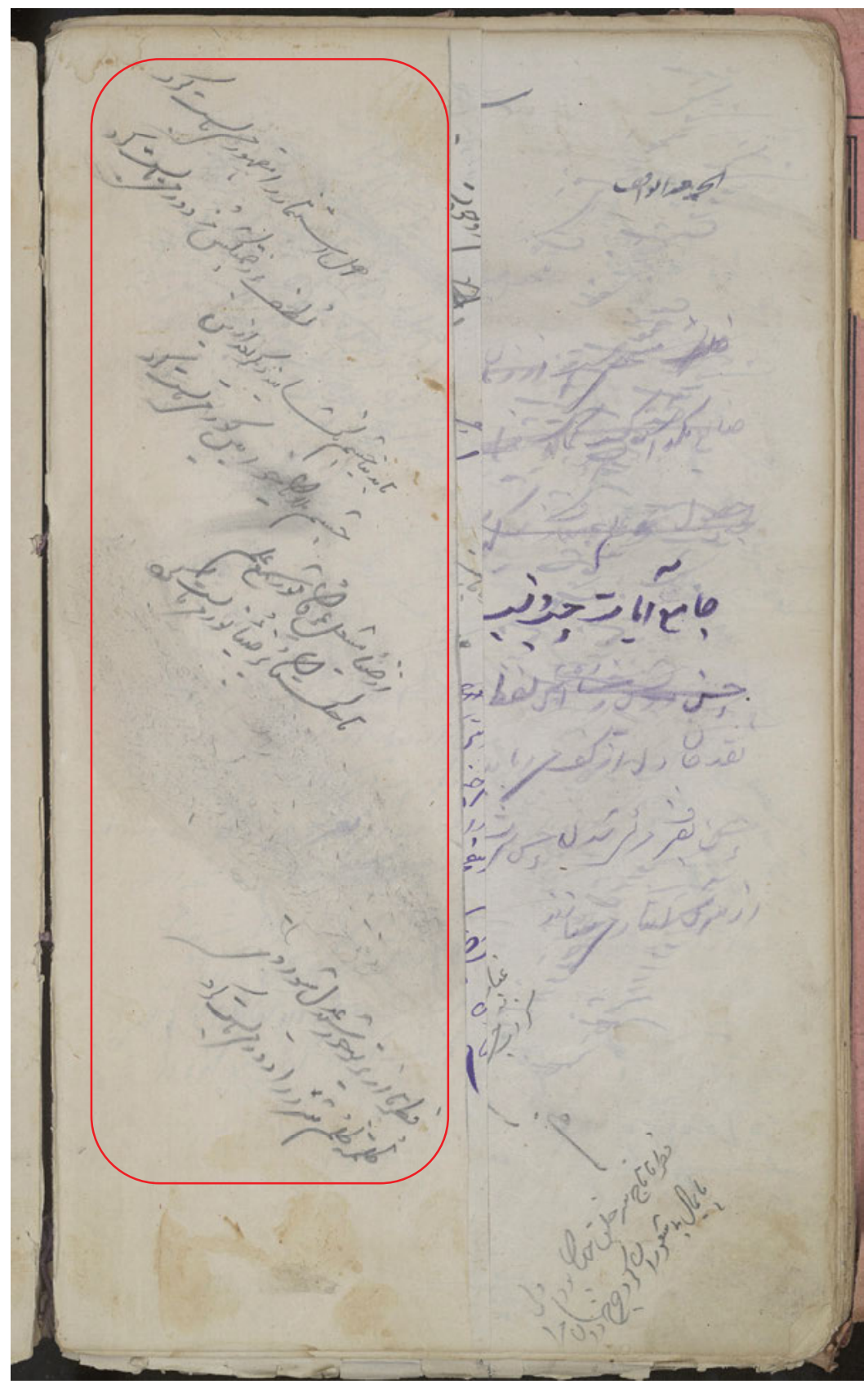

Fig. 4d: MS NLR PNS 561, fol. 51v. Longer version, lines 7 and 8 erased, attempt at blackening one word in line 4 (mullāyān). 
